\title{
Prospects and Opportunities of Vegetable Processing in India
}

\author{
Pankaj Kumar Kannaujia ${ }^{1}$, Manoj Kumar Mahawar ${ }^{1 *}$, Kirti Jalgaonkar $^{1}$, Vijay Singh Meena ${ }^{2}$ and Bhushan Bibwe ${ }^{1}$ \\ ${ }^{1}$ ICAR-CIPHET, Abohar, Punjab, India \\ ${ }^{2}$ ICAR-NBPGR, New Delhi, India \\ *Corresponding Author: Manoj Kumar Mahawar, ICAR-CIPHET, Abohar, Punjab, India.
}

Received: June 19, 2019; Published: July 04, 2019

DOI: $10.31080 /$ ASAG.2019.03.0559

\section{Introduction}

Fruits and vegetables are the most important human diet as they provide the essential minerals, vitamins and fiber required for a balanced diet. India's climatic and soil condition provide an excellent platform for the cultivation of a wider variety of vegetables. India is the second largest producer of vegetables in the world next only to China and produce about 15 percent of the world production of vegetables. During 2016-17, the production of horticulture crops was about 295.2 million tonnes from an area of 24.9 million hectares. Total area under production of vegetable in India is nearly 10.29 Mha with the production of 175 million tonnes during 2016-17 [1]. It is estimated that 20-25 per cent of the total vegetables produced in the country goes as waste owing to their seasonality and perishability. The other reasons owing to this quantum of post-harvest loss are higher respiration rate and higher moisture content (more than 85-90\%) and poor harvesting practices. Over the last decade, the area under horticulture grew by about $3 \%$ per annum and annual production increased by $5.4 \%$. Normally all vegetables are consumed unprocessed but a very few are dried, canned or pickled or sometimes frozen. Vegetables are bulky in nature leading to low value per unit that's lead to costly transportation in their fresh form. So processing of produce reduces its volume that leads to less transportation cost. For achieving this, processing of vegetable should be done near its production areas. Some of the vegetables that can be processed are given below:
Fruits and vegetables are rich sources of many beneficial phytochemicals and nutrients. However, it is generally advised to take good amount of fresh fruit and vegetables but it is not possible every time due to the high cost, throughout year availability and seasonal in nature. Therefore, processing of fruits and vegetables is mandatory and many times it is desirable. The processed forms of vegetables may be complementary increase of total consumption as well as enabling regular intake throughout the year in place of fresh form. Among the different vegetables, wax gourd, tomato and pea is processed more than $5 \%$ of their total fresh produce. Fresh vegetables are similar to living organisms and undergo normal life processes even after harvest. Loss in post harvest quality of vegetables is also affected by storage temperature, relative humidity and other factors [2]. The losses in leafy vegetables and fruit vegetables are much more than in root and tuber crops. Post harvest losses during the storage may be least, if they are stored properly under controlled conditions of temperature and humidity. In India, this type of storage facility is available only in cities at higher rent. Hence a small grower cannot use it for harvested vegetables for storage. Therefore, it could be advantageous if cold storages facilities are constructed by government agencies or by private sectors near production areas for storing the produce, which can be further used by processing industries.

\begin{tabular}{|l|c|c|c|}
\hline S. No. & Product & Processed & Can be processed \\
\hline 1 & Canned & Tomato, potato, Chinese cabbage, sweet potato & $\begin{array}{c}\text { Okra, asparagus, carrot, snap bean } \\
\text { and sweat pea }\end{array}$ \\
\hline 2 & Pickled & Cauliflower, radish, turnip, ginger and pepper & Cucumber, bittergourd, onion \\
\hline 3 & Dehydrated & $\begin{array}{c}\text { Tomato, brinjal, cabbage, cauliflower, potato, sweet } \\
\text { potato, ginger and Chinese cabbage }\end{array}$ & Onion, carrot, garlic, capsicum. \\
\hline 4 & $\begin{array}{c}\text { Fermented, fried and } \\
\text { other products }\end{array}$ & $\begin{array}{c}\text { Radish, cucumber, potato, carrot, wax gourd, carrot, } \\
\text { pumpkin }\end{array}$ & $\begin{array}{c}\text { Carrot, cabbage, chinese cabbage, } \\
\text { yam, tapioca. }\end{array}$ \\
\hline
\end{tabular}

Table 1: Status of vegetables having potential for processing. 
During the peak season there is a local glut of produce, which result in post harvest losses in terms of quality and quantity. The major factors of such losses are listed below:

- Lack of transport

- Lack of proper storage facilities

- Poor availability of suitable packaging materials in cheaper rate

- Lack of local cold storage to store the surplus

\begin{tabular}{|c|c|c|}
\hline S. No. & Crop & Average Loss (\%) \\
\hline 1 & Onion & 8.20 \\
\hline 2 & Tomato & 12.44 \\
\hline 3 & Cabbage & 9.37 \\
\hline 4 & Cauliflower & 9.56 \\
\hline 5 & Green pea & 7.45 \\
\hline 6 & Potato & 7.32 \\
\hline 7 & Tapioca & 4.58 \\
\hline
\end{tabular}

Table 2: Post-harvest losses of major vegetable crops.

Source: [3]

The food processing sector is critical to India's development. It establishes vital linkages between industry and agriculture, the main pillar of Indian economy. The growth of food processing will bring immense benefits to the economy, creating employment and raising standard of life of people across the country, especially in rural areas. Interestingly, processing industry ranks fifth in the country and employs around 13 million people directly and 35 million people indirectly. It accounts for $14 \%$ of total industrial output of the GDP. The turnover is estimated at Rs 1, 44000 crores, of which Rs 1, 11200 crores in the unorganized sector. The liberalization of the Indian economy, world trade and rising consumer prosperity have thrown up new opportunities for diversification in the food processing sector and opened up opportunity for food processing industry growth.

Presently less than $2 \%$ of fruits and vegetables are processed, even as the county ranks second in the world in terms of production. This is comparatively very meager when compared to other countries like Brazil (30\%), USA (70\%) and Malaysia (82\%). According to the Food and Agriculture Organization (FAO) [4], processing of foods can be categorized into three types: primary, secondary and tertiary. Primary processing involves basic cleaning, grading and packaging. Secondary processing means modification of the basic product to a stage just before the final preparation at the consumer's kitchen, like tomato puree. Tertiary processing leads to high-value-added, ready-to-eat products like sauces. Indi- an food processing activity is still largely based on primary processing, which accounts for $80 \%$ of the value addition. India presently produces an enormous range of processed vegetables, i.e., dried/ dehydrated and preserved vegetables such as sauces and juices, preserved onions, cucumbers and gherkins, mushrooms, green pepper in brine, dehydrated garlic powder and flakes, dried garlic, chutneys and pickles etc. India was the market leader in dehydrated onions and garlic in 2014, when the market share was about $37 \%$. The government of India has set up a separate full-fledged ministry named 'Ministry of Food Processing Industries' for the development and promotion of food processing industries. To boost vegetable processing, the Ministry is extending financial support for setting up new units, modernization and up gradation of existing units. Besides, the Agricultural and Processed Food Products Export Development Authority (APEDA) is playing a major role in the export effort of processed vegetables by providing various services to the trade and industry such as identifying new markets, regular participation both in national and international trade fairs and also launch of promotional campaigns. India's exports of processed food was Rs. 27,257.69 Crores in 2017-18, which including the share of products like Dried and Preserved Vegetable (Rs. 944.65 crores), other processed fruit and vegetable (Rs. 3404.70 crores) [5]. Estimated No. of Registered Food Processing Industries in India 1133 during 2014-15 [6].

Reason for increasing the demand of processed vegetables in India

- Less price of fresh produce, as prices are fixed based on demand and supply. In peak season, when there is glut in market, prices drop down radically and farmers didn't even get the production cost incurred.

- Increasing production of vegetables every year as productivity is increasing due to use of hybrid varieties. Hence, the surplus produce can be processed.

- Introduction of corporate sector in vegetable marketing as well as in processing industry.

- Increasing demand of processed products in domestic market as well as global market.

- Processing industries employs the labour with minimum wages and also the overall production cost must be lower. Such requirements can be easily accomplished in India as compared to European and American countries.

- Processable varieties introduced or developed indigenously which are specifically used for processing in a way to increase the recovery of final products.

- The advancement in processing techniques and machineries are now being adopted by the processors in India. 
- Government is also promoting the farmers/rural youth to establish their own processing industry by providing financial support to promote establish the small scale industries.

- There has been a drastic change in the eating pattern/food habits of the population as people are attracted towards consuming junky foods. As the food habit can't be changed easily, hence in order to enhance the consumption of vegetables, in the form of powder, flakes, paste can be done in products prepared using extrusion techniques. Many extruded products are prepared by the incorporation of powder forms of leafy vegetables like spinach, drumstick, curry leaf and fenugreek etc.

- $\quad$ People prefer ready to use and ready to eat processed products like onion and garlic paste, chutney, pickles, dried and dehydrated vegetables.

- Minimally processed salads, vegetables and other vegetables demand is increasing day by day as these products has $100 \%$ edible portion.

- Rural population is continuously reducing and urban population is drastically increasing.

- Nuclear family/single working men or women leads to more usage of processed vegetables as it will reduce the time involved in cooking.

- $\quad$ Processed vegetables have more shelf life and are less bulky in nature.

- More nutritional value per unit volume of produce.

- $\quad$ Prices of processed vegetables products are more stable as compared with fresh vegetables.

\section{Conclusion}

Owing to the nutritional benefits of vegetables, its processing is a profitable venture. Government of India is also encouraging the farmers to convert themselves into farmer-cum-entrepreneur so that they can increase their standard of living and earn more money through processing as compared to the direct sale of fresh produce. The government of India is having a target of increasing the level of processing of vegetables to $>10 \%$ till 2025 . There is also a definite scope of processed vegetables in different consumable forms for all groups of consumers throughout the year.

\section{Bibliography}

1. National horticulture board database -2018, Ministry of agriculture, Government of India.

2. Kader AA. "Postharvest technology of horticulture crops". Third Edition, (2002).

3. Jha SN., et al. "Report on assessment of quantitative harvest and post-harvest losses of major crops and commodities in India”. ICAR-All India Coordinated Research Project on Post-Harvest Technology, ICAR-CIPHET, P.O.-PAU, Ludhiana-141004 (2015).

4. Food and Agriculture Organization (FAO) database.

5. Agricultural and processed food products export development authority (APEDA, 2018).

6. Ministry of food processing industries, government of India.

\section{Volume 3 Issue 8 August 2019 \\ (C) All rights are reserved by Pankaj Kumar Kannaujia., et al.}

